\title{
No Need to Beg China? Taiwan's Membership of the Asia-Pacific Economic Cooperation as a Contested State
}

\author{
Ming-chin Monique Chu \\ University of Southampton \\ Email: M.M.Chu@soton.ac.uk
}

\begin{abstract}
:
This article examines the process, causes and repercussions of the accession of Taiwan, as a contested state, together with China, to the Asia-Pacific Economic Cooperation in 1991, the first inter-governmental organization that Taipei has joined since 1971. Based on an analysis of elite interviews, primary and secondary data, the paper traces the under-explored diplomatic history. It argues that changes in Taiwan's domestic and external environments as well as during the diplomatic process have accounted for Taipei's admission, instead of the China factor alone. The four positive effects of accession on Taiwan's international space are explored, as are the implications of the study for Taiwan's continuous survival as a contested state. By undertaking a nuanced analysis of an important yet under-studied milestone in the contested state's struggle to mitigate international isolation, the article sheds light on the study of Taiwan's external ties amid the sovereignty dispute between Taipei and Beijing.
\end{abstract}

Key words: Asia-Pacific Economic Cooperation, contested state, Taiwan and China sovereignty dispute, convergence of interests.

Acknowledgements: I owe special thanks to the Centre for International Studies, University of Cambridge, as well as the Chiang Ching-kuo Foundation for International Scholarly Exchange (RG-005-U-13) for generous research travel support. I very much appreciate the useful comments on earlier drafts of the paper by Yu-shan Wu, Andrew Scobell, Scott L. Kastner, Dennis V. Hickey, Gerald Chan, as well as three anonymous reviewers.

\section{Introduction}

After 1949, both the Republic of China (ROC) on Taiwan and the People's Republic of China (PRC) strove to win recognition and legitimacy from the international community. In 1971, Taiwan lost its seat in the United Nations, 
becoming what Deon Geldenhuys describes as a contested state. ${ }^{1}$ Contested states constitute anomalies in the conventional inter-state system as they often lack sufficient international recognition. ${ }^{2}$ Although some of them have demonstrated a certain degree of statehood by viably ruling their domestic constituents and showing domestic sovereignty, ${ }^{3}$ the international community challenges their purported statehood. ${ }^{4}$ Examples of contested states include Palestine, Kosovo, Taiwan, and Transnistria. Since 1971, Taiwan has received de jure recognition from a minority of confirmed states, lacked sufficient international legal sovereignty, ${ }^{5}$ and had limited participation in inter-governmental organizations (IGOs) ${ }^{6}$ However, it has achieved domestic sovereignty by effectively controlling events within its borders. Moreover, it has expanded its functional ties with a majority of confirmed states and used its economic power to win some degree of international recognition, thereby mitigating its level of isolation as compared to that of other contested states. ${ }^{7}$ Kosovan and Transnistrian officials have even regarded Taiwan as an example to follow. ${ }^{8}$

This paper presents the findings of original research on an important yet underexplored case of Taiwan's admission to the Asia-Pacific Economic Cooperation (APEC) in $1991 .{ }^{9}$ It moves beyond a state-centric analytical framework to explore how and why APEC became the first IGO that Taipei joined as a contested state, despite Beijing's initial opposition. The first enlargement of APEC took place in Seoul in November 1991, two years after its formation, with Taiwan, the PRC, and Hong Kong (the so-called Three Chinas) admitted as new members. By including three economies that had strong regional links, APEC strengthened its "stature as the single largest forum speaking on the subject of trade liberalization." ${ }^{10}$ Although APEC accession was a milestone in Taipei's struggle as a contested state, it has not been thoroughly examined in the scholarly literature. This paper fills the void by explaining the process, causes and repercussions of the accession through original research.

In terms of methodology, a qualitative single case study approach was adopted for this study because of the paucity of existing knowledge about the chosen area of study. ${ }^{11}$ This approach allows the researcher to focus on marshalling facts in order to

\footnotetext{
${ }^{1}$ Geldenhuys 2009.

${ }^{2}$ Ibid; Berg and Toomla 2009.

${ }^{3}$ Krasner 1999, 2001.

${ }^{4}$ Geldenhuys 2009; Ker-Lindsay 2012, 19-20.

${ }^{5}$ Krasner 1999, 2001.

${ }^{6}$ Cho 2005; Wang 2006; Chang 2010.

${ }^{7}$ For Taiwan's evolving status in the international system, see Yahuda 1996; Hickey 2007; Fell 2012, 151-170.

${ }^{8}$ Ker-Lindsay 2012, 19-20; Ignatiev 2012.

${ }^{9}$ In June 1989, Australian Prime Minister Robert Hawke called for the establishment of a more formal intergovernmental vehicle of regional co-operation resulting in the birth of APEC. See Hawke 1989, 1994, 431; Funabashi 1995, 58-61.

${ }^{10}$ Hoon 1991.

${ }^{11}$ Gerring 2004.
} 
offer a holistic description of the complex case in question and to retain the meaningful characteristics of real-life events. ${ }^{12}$ Research methods included in-depth interviews, and the collection of primary and secondary materials. ${ }^{13}$ Major interviewees included American and Taiwanese officials and business leaders involved in the diplomacy leading up to Taiwan's accession. Library research was carried out in the US, Taiwan and Mainland China.

The paper is composed of four sections. After the introduction, the second section uses the method of process tracing ${ }^{14}$ to detail the pertinent diplomatic history, highlighting the key events and multiple players of state and non-state capacity. The third section argues that a combination of factors emanating from changes in Taiwan's domestic and external environments as well as from the diplomatic process has accounted for Taipei's diplomatic breakthrough. Taiwan's domestic changes, namely its economic success and the pursuit of pragmatic diplomacy as a new foreign policy initiative, were assets for its APEC admission. Externally, Beijing's post-1978 economic reforms and the Tiananmen Incident were also conducive to Taiwan's accession. Moreover, the bottom-up approach to regionalism prior to APEC allowed Taiwanese business elites to utilize their accumulated connections within regional non-governmental organization (NGO) networks to lobby for Taiwan's membership to compensate for the handicapped formal channels of diplomacy stemming from Taipei's status as a contested state. During the diplomatic process, decisions by APEC to define members as economies and to simultaneously admit the Three Chinas further facilitated Taipei's entry. So did the convergence of interests among pertinent multiple players. Eventually, creative formulae were found resulting in Taiwan's accession. The final section discusses the four positive effects of accession on Taiwan's position as a contested state and the implications of the study for Taipei's continuous survival as a contested state.

\section{Diplomatic Process of Taiwan's Accession}

The diplomatic process leading up to APEC's first enlargement comprised the pre-negotiation phase from early 1989 to the July 1990 Singapore meeting and the negotiation period from October 1990 to October 1991. The enlargement issue was problematic for APEC because of Taipei's sovereignty dispute with Beijing. According to Richard H. Solomon, former Assistant Secretary of State for East Asian

\footnotetext{
12 Yin 1994, 2.

${ }^{13}$ Interviews were carried out in 1997, 1998, 2013, 2014 and 2015. While interviews can help correct distortions in primary and secondary materials, the use of the latter can compensate for the weaknesses of the former. See Tansey 2007.

${ }^{14}$ Process tracing enables us to examine multiple interaction effects, "where it is difficult to explain outcomes in terms of two or three independent variables." See George and Bennett 2005, 206.
} 
and Pacific Affairs, "The issue was constant. That is, would China agree to it [Taiwan's admission to IGOs]? Then there would be negotiations on the language how would Taiwan be described?" 15 The diplomacy leading to enlargement, however, was far more complicated than what Solomon had described.

\section{Pre-negotiation Period}

Before the formal negotiations, a number of actors had worked for or against Taiwan's entry. They included the Australian, American and Chinese governments, the Association of Southeast Asian Nations (ASEAN) countries, the Taiwanese state and non-state actors.

Before APEC's inception, Taiwan's private sector elites had started lobbying for Taipei's membership. In April 1989, heavyweight Taiwanese businessman C.F. Koo 幸振甫 met the Australian envoy Richard Woolcott during the meeting of a regional NGO, namely the Pacific Economic Cooperation Council (PECC), in San Francisco, arguing that Taipei's designation would not become a problem so long as it could join the regime. $^{16}$

Australia initially sought the inclusion of Three Chinas, ${ }^{17}$ but later decided to defer the issue. In March and April 1989, Woolcott consulted the opinions of proposed APEC members on the issue. ${ }^{18} \mathrm{He}$ concluded that "most countries believed that China should become a participant, as well as Taiwan and Hong Kong, as major regional economies, if the difficulties surrounding their status could be overcome."19 On 15 May, the Australian Minister of Foreign Affairs Gareth Evans expressed Canberra's desire to involve Taiwan in the regime: "Because of the importance of the Taiwanese economy and its links with other regional economies, we would also like to see Taiwan - although recognized by most potential participants as part of the PRCassociated in some way with the initiative."20

In May, Woolcott met with the Chinese Premier Li Peng 李鵬, Foreign Minister Qian Qichen 錢其琛 and the Minister of Foreign Economic Relations and Trade Li Lanqing 李嵐清 in Beijing. ${ }^{21}$ China insisted that if the meeting were to be held at a formal, intergovernmental level, only sovereign states should participate, not Taiwan and Hong Kong. ${ }^{22}$ Subsequently, Woolcott deferred the issue.

\footnotetext{
${ }^{15}$ Interview with Richard H. Solomon, former Assistant Secretary of State for East Asian and Pacific Affairs, Washington DC, 1 April 1998.

${ }^{16}$ Interview with a Taiwanese participant in the meeting, Taipei, 28 October 1997.

${ }^{17}$ Far Eastern Economic Review, 1989. "Unspecific Pacific," 144 (19), 20.

${ }^{18}$ These included New Zealand, Japan, South Korea, and the ASEAN member states.

${ }^{19}$ Woolcott 1994.

${ }^{20}$ Evans 1989; Evans and Grant 1991, 126.

${ }^{21}$ Woolcott 1994.

${ }^{22}$ Funabashi 1995, 65.
} 
In Washington DC, Woolcott met US officials and regional NGO leaders to discuss membership issues. ${ }^{23}$ The focus was to establish APEC on a "six plus six" formula, with six ASEAN countries "counterweighted" by six non-ASEAN members in order to allow APEC to get off the ground and to assure ASEAN of its central role in the regime.

According to Robert Zoellick, the then State Department Counsellor, the immediate membership of Three Chinas would hinder the US objective of getting APEC off the ground. ${ }^{24}$ Furthermore, this formula was to convince ASEAN of its key role in the creation of APEC. From the outset, ASEAN members were ambivalent about the participation of the three Chinese economies. ${ }^{25}$ Some declined to include China without Hong Kong and Taiwan fearing that ASEAN's collective voice would be muted. ${ }^{26}$ Others were suspicious of Taiwan, dreading that the latter's friendly ties with Washington would threaten ASEAN's position. ${ }^{27}$

In Washington DC, Woolcott gave an American member of the Pacific Basin Economic Council (PBEC), another regional NGO, the briefing papers on the Australian initiative. On 24 May, these papers were sent to Koo, the then-deputy international president of PBEC. Given Koo's close relations with the Taiwanese authorities in his capacity as a member of the Central Standing Committee of the ruling Kuomintang, these papers must have reached the Taiwanese government. ${ }^{28}$

After Woolcott's second-round trip came the Tiananmen Incident on 4 June 1989, which resulted in Beijing's temporary diplomatic isolation. Tiananmen helped the initiators of APEC confirm the existing consensus to start APEC on a "six plus six" basis. On 7 July, the US Secretary of State James Baker stressed that ChinaTaiwan issue was a political problem of long standing, so Washington preferred getting APEC established on a "six plus six" formula. ${ }^{29}$

By this time, the exclusion of Taiwan from the inaugural regime was ensured. The major causes were Beijing's opposition to Taipei's membership, the consensus on starting APEC with a smaller grouping of twelve, and ASEAN's apprehension of a possible weakening of its position due to the Three Chinas' immediate inclusion. Tiananmen created a revulsion against Beijing but did not cause the exclusion of the

\footnotetext{
${ }^{23}$ Australian Background 1989; a private correspondence between an American PBEC participant and his Taiwanese counterpart, 24 May 1989; interview, Richard H. Solomon.

${ }^{24}$ Telephone interview with Robert Zoellick, former State Department Counsellor, Washington DC, 1 April 1998. Also see interview, Richard H. Solomon.

${ }^{25}$ Bonnor 1990, 61.

${ }^{26}$ Funabashi 1995, 65.

${ }^{27}$ Koo 1989.

${ }^{28}$ Woolcott's visit to Taipei was not included in his published official itinerary. Interview with C. K. Chang, an economist involved in the diplomatic process from a think tank run by Koo's conglomerate, Taipei, 28 October 1997.

${ }^{29}$ Baker 1989.
} 
three from the 1989 meeting. In September, a Senior Official Meeting (SOM) in Sydney decided that the three entities would not be admitted to the inaugural meeting. However, Taiwan continued lobbying for membership. In the September PECC meeting in New Zealand, Koo argued that since PECC had decided to support APEC, PECC should demand Canberra invite all the PECC member countries, including Taiwan, to the meeting.

Meanwhile, Taiwan was offered some conciliatory arrangements to allow it to be “associated” with the inaugural meeting. As Frederick Chien 錢復, Taiwan's then foreign minister recalled, "We were allowed to send one or two people to Australia so as to establish contacts with APEC delegations outside the formal meeting." ${ }^{30}$ The Taiwanese delegation included Tzu-dan $\mathrm{Wu}$ 吳子丹, C.F. Koo, and C.K. Chang 張錦 崑. ${ }^{31} \mathrm{Wu}$ was a career diplomat. Koo was the deputy international president of PBEC. Chang was an economist from Koo's think tank. Only Koo was formally invited to the APEC opening banquet because of his position in PBEC. ${ }^{32}$

By utilizing his connections established in regional NGOs since 1969, Koo collected information for Taipei and lobbied for Taiwan's membership by meeting officials and his NGO counterparts during the 1989 meeting. On 5 November, he met Japanese and South Korean ministers, and the Indonesian PECC representative Jusuf Wanandi. He also phoned Richard H. Solomon seeking American support. During the banquet, Koo lobbied the Australian Prime Minister, Robert Hawke, the Australian Foreign Minister, Gareth Evans, as well as the Singaporean representative Lee Hsien Loong for Taiwan's membership. According to Evans, Beijing had criticized Canberra for having invited Koo to the banquet, and refused to send the Chinese ambassador to Australia and the Chinese PECC delegate to the event. Some participants expressed their support for Taipei while suggesting that Taiwan should work out a feasible formula. ${ }^{33}$

On 7 November, APEC members discussed the enlargement issue. The positive attitudes of South Korea, Japan and Canada were countered by ASEAN's reservations, reaching no conclusion on enlargement.

In March 1990, the first SOM in Singapore concluded that on this issue it would be necessary to proceed by consensus despite internal discord over the question of timing and modalities. ${ }^{34}$ The second SOM in May addressed the former issue by establishing the principle of simultaneous participation, with still no resolution on the

\footnotetext{
${ }^{30}$ Interview with Frederick Chien, former Minister of Foreign Affairs, Taipei, 24 October 1997.

${ }^{31}$ Interview, C. K. Chang; Koo 1989; Huang, Shuling. 1991. "Guzhenfu yu Yataijinghehui” (C.F. Koo and APEC), Lianhe bao, 30 September.

${ }^{32}$ Interview with Richard H. Fairbanks, the then President of PECC, Washington DC, 3 April 1998.

${ }^{33}$ Koo 1989.

${ }^{34}$ APEC1990a.
} 
latter. $^{35}$

Disagreement over enlargement continued during the first few days of the second APEC ministerial meeting in July. While some ASEAN members considered the inclusion premature, others willed their entry to take place as soon as possible. ${ }^{36}$ However, a breakthrough emerged during a five-hour lunch attended by heads of delegation only. ${ }^{37}$ Members agreed that consultations should proceed with the three economies with a view to reaching modalities acceptable to all parties involved for the simultaneous participation of the three as soon as possible. ${ }^{38}$ Furthermore, the decision making involved would be a "collective process," in which the consultations would be referred back to the ministers at APEC that would reach a consensus on the final inclusion of the three. ${ }^{39}$

Behind this decision laid a complex political drama. First, Taiwan's effort to lobby for its inclusion continued, with its state and non-state actors working before, during and after the Singapore meeting. ${ }^{40}$ As one participant recalled, "Taiwan's role at that point was lobbying different delegations." ${ }^{41}$ In contrast, Beijing reiterated its refusal to allow Taiwan and Hong Kong to become members because "they are territories." 42

Second, Washington continuously tried to resolve the enlargement issue. State Department officials kept contact with Seoul, the designated host of 1991 APEC, and worked closely with the Taipei representative in Washington DC, Mao-shih Ding 丁 檚時. Taipei and Washington agreed that Seoul should take the lead in negotiating with Beijing. Washington viewed Seoul as a less difficult negotiating partner for the Chinese than the US would be. If Washington worked as a mediator, issues about its Taiwan policy would have become part of the discussion, further complicating the negotiation. Concurrently, America knew that Seoul was willing to undertake such a project and had confidence in the skill of the person chosen to undertake the mediation, Lee See-young. As Robert Fauver recalled, "Once America had made that determination to get the Koreans to work in the front, the US delegation worked behind the scenes during the surroundings of the meetings and Baker worked on the agreement at the lunch itself." 43

The third point involved the wording of the July agreement and ASEAN

\footnotetext{
35 APEC 1990b.

36 "No consensus on whether to admit China, Taiwan and HK," Straits Times, 31 July 1990.

${ }^{37}$ Interview with Robert Fauver, former Deputy Assistant Secretary of State for East Asian and Pacific Affairs, Washington DC, 1 April 1998.

${ }^{38}$ APEC 1990c; Youngblood 1990.

${ }^{39}$ Solomon 1990a; Youngblood 1990.

${ }^{40}$ Interviews, C. K. Chang and Robert Fauver.

${ }^{41}$ Interview, Robert Fauver.

${ }^{42}$ Youngblood 1990.

${ }^{43}$ Interview, Robert Fauver.
} 
members. As one participant observed, "Technically it allowed ASEAN to say "we have not yet agreed' but it got the process going to see if there would be a solution... So they still had a chance to say "no' even though the process had started." 44 From Washington's standpoint, to maintain ASEAN's comfort level was important for APEC, and "to maintain that comfort level was critical to answer the Three Chinas' question." 45

\section{Formal Negotiations}

Following the July 1990 agreement, consultations kick-started with Seoul as the mediator and Beijing and Taipei as the negotiating parties concerned. Behind the scene was the "silent but active bystander" - America. ${ }^{46}$ Once the formal negotiations began, the key players became diplomats from Seoul, Taipei, Beijing and Washington. Taiwanese non-state actors moved into the background.

Nine rounds of negotiations took place from October 1990 to October 1991. Taiwan negotiated with Korea alone three times; the rest of the negotiations were conducted between Korea and Taiwan and Korea and China in a "simultaneous but non-overlapping" manner. There was no face-to-face negotiation between Beijing and Taipei. Locations of negotiations ranged from Beijing, Taipei, Seoul, Washington DC, to New York. ${ }^{47}$

In October 1990, the Taiwanese negotiator Tzu-dan Wu set out Taipei's position in Seoul. ${ }^{48}$ In January 1991, Lee embarked on his mission to incorporate the three entities into APEC. From 19 to 23 August, crucial negotiations took place in Seoul, with Korea proposing a compromise plan concerning Taipei's designation in APEC. ${ }^{49}$

However, no agreement emerged until the August SOM meeting in Kyongju. "Lee received the news by phone of Taipei's acceptance when he was chatting with Bob Fauver in his hotel room, who congratulated him on the breakthrough," wrote Yoichi Funabashi in his account of the negotiation. ${ }^{50}$ APEC members then endorsed the secret Memoranda of Understanding (MOUs) which set out the terms for the enlargement, and announced the Three Chinas' participation in the November ministerial meeting. ${ }^{51}$

In late September in New York, the final agreement on the wording of the Korea-

\footnotetext{
${ }^{44}$ Ibid.

${ }^{45}$ Ibid.

${ }^{46}$ Ibid.

${ }^{47}$ Chang 1991; interview with John Chang, the then Vice Minister of Foreign Affairs, Taipei, 24 March 2015.

${ }^{48}$ Yin 1991.

${ }^{49}$ Ibid.

${ }^{50}$ Funabashi 1995, 74.

${ }^{51}$ APEC 1991.
} 
PRC MOU and the Korea-ROC MOU was reached at midnight on the morning that the Chinese foreign minister was due to leave. On 2 October, the Korea-PRC MOU was signed. On 15 October, the Korea-ROC MOU was signed concluding the pertinent negotiations.

It is noteworthy that Washington had continued to work behind the scenes trying to find a solution. As Fauver recalled, "During the discussions, from the beginning to the end, we talked to all participants on a number of different occasions, trying to move all sides towards the middle. ${ }^{, 52}$ Furthermore, Washington continued to express its support for Lee and the proposed enlargement. ${ }^{53}$ As Fauver noted, "All three sides knew that they could not split us from See-young. That was important to the process." 54 During the US-Korea summit on 2 July, US president George Bush supported the enlargement. ${ }^{55}$

Once the negotiations started, thorny questions pertaining to the sovereignty dispute between Beijing and Taipei were brought to the negotiation table. They involved issues ranging from the timing of membership, the name of participants, the level of representation, the ministries of representation, to the future hosting of APEC meetings. Procedural questions were also negotiated, such as who would enter the door first, and whether there would be the use of national flags. ${ }^{56}$

As Lee recalled, the two sides were initially "far apart and compromise seemed elusive," 57 with both merely agreeing not to use flags in the meetings, a consensus already reached when APEC was established.

Besides, the contrasting focus of the two sides loomed large, with Taiwan concerned about substance while Beijing concentrated on process. "Taiwan was interested in the substance of APEC first and the process second. My foreign ministry friends in Taiwan understood the longer-term interest was more on the substantive benefits of APEC than on the diplomatic benefits... Conversely, for Beijing, the focus was on process first, process second and process third, with a focus on substance coming in last," observed an involved American official. ${ }^{58}$ On the issue of timing, for example, Beijing initially suggested that the PRC should be the first to be admitted, with the right to veto new applicants. ${ }^{59}$ Others, however, insisted on the simultaneous admission of all three in accordance with a prior principle established by APEC.

Taipei's designation was a sticking point in negotiations. Both sides were initially far apart on this topic. Taiwan first put its official name "ROC" on the table,

\footnotetext{
${ }^{52}$ Interview, Robert Fauver.

${ }^{53}$ Solomon 1990b; "Fact Sheet: APEC." 1991.

${ }^{54}$ Interview, Robert Fauver.

${ }^{55}$ Solomon 1991; interview, Frederick Chien.

${ }^{56}$ Ibid.

${ }^{57}$ Funabashi 1995, 73

${ }^{58}$ Interview, Robert Fauver.

${ }^{59}$ Interview, Richard H. Solomon.
} 
but it was rejected by the PRC. Beijing demanded that Taipei agree to enter APEC as a province of China by using names including "Taipei-China" or "Taiwan-China." 60 Taiwan disagreed. Also presented on the table were the Asian Development Bank (ADB) model and the formulation proposed in General Agreement on Tariffs and Trade (GATT) discussions. ${ }^{61}$ While Taipei intended to choose a name that would not imply the inclusion of Taiwan as part of the PRC, Beijing preferred names implying a lack of Taiwan's independence from the Mainland. ${ }^{62}$ Eventually, Lee put forth "Chinese Taipei," known as the Olympic model, ${ }^{63}$ on the table, and both sides agreed.

Equally thorny was the protracted question of who would represent Taipei in APEC. Taipei initially insisted on sending its foreign minister to APEC meetings on an equal footing vis-à-vis Beijing, but Beijing disagreed. Subsequently, Taiwan agreed that only its ministers in charge of APEC-related economic affairs shall attend the meetings, not its foreign minister nor vice foreign minister. However, the Taipei delegation could include officials of foreign and other ministries at or below the level of department directors. ${ }^{64}$ As Chien explained, "Foreign ministers attend APEC mainly to conduct private bilateral talks outside the formal meetings, whereas APEC is a forum to discuss issues of non-political nature. So whether our foreign minister attends APEC would not influence our main interest... Because APEC discusses trade matters, we insist on the participation of our minister of economic affairs. We have to be treated as an equal in this regard., 65

\section{Factor Analysis}

Arguably, Taipei successfully joined APEC because of a combination of factors emanating from Taiwan's external and domestic environments as well as from the diplomatic process. The external environment focuses on the trend of regionalism and the China factor, whereas the domestic environment refers to political and economic changes at home.

\section{External and Domestic Changes}

The first external factor refers to the shift in regionalism in the Asia-Pacific region. For nearly three decades prior to APEC's inception, regionalism was

\footnotetext{
${ }^{60}$ Chang 1991, 332; Funabashi 1995, 74.

${ }^{61}$ Chang 1991, 315; interview, Robert Fauver. For the ADB model, see Hsieh 1994; Deng 1997, 72; interview with Samuel Hsieh, former ADB staff member, Taipei, 4 November 1997.

${ }^{62}$ Interview, Robert Fauver; Chang 1991, 332.

${ }^{63}$ Chan 1985.

${ }^{64}$ Funabashi 1995, 74-75.

${ }^{65}$ Interview, Frederick Chien.
} 
characterized by a bottom-up approach with a strong societal involvement because of deepening regional economic interaction. The formation of APEC, however, signalled the shift towards state-led economic regionalism, driven by a sense of economic insecurity among members involved in the face of a multilateral trading system under threat.

The shift towards state-led economic regionalism created problems for Taiwan's accession because of Taipei's status as a contested state. While Taiwan's business leaders had deepened connections with their regional counterparts and influences in regional NGOs, its state actor was unable to join the inaugural IGO in 1989.

However, the long-standing bottom-up development of regionalism created opportunities for Taiwan's accession because it enabled Taiwanese business leaders to take part in regional NGOs thereby deepening ties with their regional counterparts. They utilized these NGOs as platforms of diplomacy to help Taipei's bid for APEC membership in pursuit of national interests. Because of Taiwan's contested statehood, these informal diplomatic channels became important in partly alleviating Taipei's isolation for the sake of gaining APEC membership.

The second external factor refers to China's domestic transition, namely the Tiananmen Incident and Deng Xiaoping’s economic reforms after 1978.

Some contend that the Tiananmen Incident led to the exclusion of the three Chinese economies from the inaugural APEC meeting; but for the Incident China would have been invited to Canberra in 1989, which might have created more obstacles for Taiwan's entry. ${ }^{66}$ However, this explanation is problematic in that the exclusion of the three entities from the Canberra meeting primarily resulted from a consensus to start APEC with a smaller grouping, and such a consensus predated the Incident. As Fauver argued, "I don't think it (Tiananmen) affected the membership question or the timing of the membership question." $" 67$

However, the Incident indirectly influenced Taiwan's accession. With its strategic position lessened by East-West détente in the late 1980s and its international reputation damaged because of Tiananmen, China suffered a severe blow in its international importance and its bargaining power vis-à-vis relevant parties regarding Taipei's accession weakened accordingly. Furthermore, the Incident challenged the legitimacy of the Chinese Communist Party (CCP) regime. To make up for legitimization deficits, Beijing aspired to improve its foreign ties so as to restore its great-power status and to regain its international acceptance. ${ }^{68}$ Although hard-liners became dominant after the massacre, the CCP would still have to pursue an open-door policy in order to sustain economic growth, which would be central to regime

\footnotetext{
${ }^{66}$ Bonnor 1990, 60; Yin 1991.

${ }^{67}$ Interview, Robert Fauver.

${ }^{68}$ Kim 1995, 466.
} 
legitimacy. Hence, friendly relations with the West were deemed important. The aftermath of Tiananmen thus reinforced China's desire for its membership of APEC. Given APEC's preference for Taipei's accession, Beijing had to make concessions on Taiwan's admission during the negotiations that began months after Tiananmen in order to make its own accession possible.

Deng's post-1978 economic reforms ${ }^{69}$ comprised the expansion of trade and the encouragement of foreign investment. China's link with the international economy deepened, especially in the Asia-Pacific region, ${ }^{70}$ and Beijing decided to embrace international economic organizations including APEC. ${ }^{71}$ These changes were conducive to Taiwan's APEC membership because China consequently saw multiple economic interests in its APEC accession. The membership could help Beijing manage its relations with pertinent market-oriented economies, engage itself in certain economic rule-making, seek foreign resources for economic co-operation, and pursue trade liberalization. APEC's aim to save a shaky multilateral trading system further matched China's interest as a growing trading power. Because China's willingness to join APEC was strong for the aforementioned political and economic considerations, it could not afford to be excluded. Hence the principle of simultaneous participation enhanced the cost of Beijing's initial move to block Taipei's membership.

Taiwan's domestic transition in the late 1980s further created opportunities for its APEC membership. Politically, the move towards pragmatic diplomacy after 1988 was conducive to accession because Taipei was no longer constrained by the zero-sum rationale that had dictated its strategy towards IGO membership. Economically, Taiwan's trade liberalization reinforced its preference for joining APEC and Taiwan's increasing economic regional links through overseas investment, ${ }^{72}$ intra-regional trade, and technology transfers enhanced its desirability by APEC. Because the formation of APEC was driven by an urgent regional need to establish a grouping in order to secure an open trading system, Taiwan attracted APEC because its accumulated economic power could enhance the collective strength of the regime. This demonstrates that the well-documented economic statecraft was functioning. Taiwan's economic clout further facilitated the active engagement in regional NGOs by its business leaders, which, in turn, contributed to Taiwan's bid.

\section{Effects of the Decisions by APEC}

\footnotetext{
${ }^{69}$ Shirk 1996.

${ }^{70}$ Hartland-Thunberg 1990, 55-62; Lardy 1994, 71.

${ }^{71}$ Deng 1997.

${ }^{72}$ In 1989, Taiwan's investment ranked second in the Philippines. In 1990, Taiwan was the number one foreign investor in Malaysia. See Cheng 1992, 42.
} 
Enabling factors emanating from the diplomatic process included two decisions by APEC prior to negotiations. The first was to define APEC as an organization composed of "economies" rather than "states." The second referred to the principle of simultaneous participation. Arguably, these rules were the accommodations APEC made in order to facilitate Taiwan's inclusion because the IGO regarded Taiwan, despite its contested statehood, as an asset to the nascent regime due to its economic power.

Each rule influenced the negotiations as follows. The first decision, made in 1989, aimed to make the involvement of Taiwan (and Hong Kong) possible. ${ }^{73}$ Specifically, the rule was to bypass the issue of statehood and sovereignty that had irritated Beijing over Taipei's IGO membership, thereby minimizing the emergence of political disputes in negotiations on enlargement.

The second principle of simultaneous participation, as argued earlier, constrained Beijing's freedom of action to block Taipei's inclusion. If the PRC blocked Taiwan's membership, it would be concurrently excluded as well. ${ }^{74}$ Once the price of exclusion became too high because of its aforementioned interests, Beijing had to accept this rule in order to join the regime.

\section{Concessions by Beijing and Taipei amid APEC Incentives}

Another enabling factor from the diplomatic process resulted from concessions made by Taipei and Beijing partially because of perceived incentives offered by APEC membership. As William Habeeb argues, "All negotiations involve concessions and all successful negotiations involve convergence." 75 Both parties made concessions during the negotiations, finally reaching a convergent point from their initially disparate positions over Taiwan's membership. Because perceived political and economic incentives offered by APEC made the price of exclusion exceedingly costly, concessions became desirable.

For Beijing, its major concession was to consent to Taiwan's membership, agreeing to a format that would allow dual Beijing-Taipei membership of the new IGO. Before the launch of APEC, Beijing had insisted that members should be limited to sovereign states in order to keep Taiwan and Hong Kong out of the IGO. In July 1990, Beijing reiterated the same stance. In the initial rounds of negotiations, however, Beijing gave consent to Taipei's membership on condition that Taiwan would join APEC as a province of China. However, it eventually agreed to terms that would allow Taipei to become a member, yet terms that would not necessarily imply

\footnotetext{
${ }^{73}$ Interview, Richard H. Solomon.

${ }^{74}$ Interviews, Frederick Chien and Richard H. Solomon.

${ }^{75}$ Habeeb 1988, 28.
} 
that Taiwan was a province of China. Nonetheless, it still managed to prevent Taiwan from using its official designation and to limit the political presence of Taipei in APEC by ruling out the participation of its foreign minister and vice foreign minister. Arguably, China's concessions had shown, as of the early 1990s, what Gary Klintworth describes as a growing Chinese tolerance of Taiwan's new international role. $^{76}$

Beijing's concessions can be partly explained by the strong economic and political incentives offered by APEC membership. In economic terms, as argued earlier, APEC attracted China because it could offer the country multiple benefits. First, APEC's objective to push the conclusion of the Uruguay Round negotiations would be in China's interest as a growing trading power. According to a Chinese official, to join APEC agreed with Beijing's outward-oriented economic reforms. ${ }^{77}$ Second, China aspired to engage in this rule-making regional mechanism in order to create a predictable environment for its economic development. ${ }^{78}$ Finally, Beijing regarded its accession to APEC useful for its GATT membership.

Politically, APEC's attraction to Beijing was two-fold. First, the regime created a regional setting in which Beijing could pursue its bilateral diplomacy outside formal discussions. ${ }^{79}$ After its admission to APEC in Seoul, for instance, the Chinese delegation met the Korean president Roh Tae Woo to discuss bilateral issues, paving the way for the Beijing-Seoul normalization in 1992. Second, accession served as a political asset to Beijing because it marked China's return to the international community after Tiananmen.

Taipei yielded mainly in the name and level of representation for its delegation to APEC. As illustrated above, even before the negotiations Taipei had recognized the external constraints imposed upon its pursuit of membership, thereby indicating its willingness to concede regarding its designation in APEC. Although Taipei put its official designation on the negotiation table, it was highly likely that Taipei knew that it would attend APEC using a different name.

Taipei's priority of joining APEC was clear from the outset. According to Chien, "There is a total consensus in the government that we should participate. The only concern is how we can minimize damage to our country. If we do not participate, it will violate our logic of pragmatic diplomacy." $\$ 80$

To achieve its objective of admission, Taipei was ready to make concessions considering the strong economic and political incentives offered by APEC. In

\footnotetext{
${ }^{76}$ Klintworth 1995, 505.

${ }^{77}$ Zhongguo shibao, 12 November 1991.

${ }^{78}$ Klintworth 1995, 497.

${ }^{79}$ Deng 1997, 62.

${ }^{80}$ Interview, Frederick Chien.
} 
economic terms, APEC appealed to Taiwan for four reasons. First, APEC aimed at maintaining an open trading system thereby serving the economic interest of Taipei as an aggressive export maximizer. Second, accession would help Taipei manage its interdependence with the neighbouring countries. ${ }^{81}$ Third, Taiwan shared APEC's objective of economic liberalization. Fourth, Taiwan could use APEC to seek support for its GATT membership.

In political terms, membership would create both symbolic and substantive gains for Taiwan because APEC would become the first IGO for Taipei to join since 1971, despite Chien's claim that the main reason for Taiwan's accession was "economic, not political" considerations. ${ }^{82}$ Symbolically speaking, the act of entering the first IGO since the inception of its contested statehood would enhance Taiwan's official visibility and improve its international standing. More importantly, Taiwan could use the regime to promote its interests of "dual recognition"; by concurrently becoming a member together with the PRC, Taipei could seek de facto recognition of two separate political entities on each side of the Taiwan Strait among APEC members. After all, confirmed states could grant Taiwan, as a contested state, de facto recognition through participation in multilateral conferences with the latter. ${ }^{83}$ Besides, accession could help Taipei improve its political legitimacy at home by presenting the IGO membership to its domestic audience as a product of the success of its pragmatic diplomacy in response to the growing desire among its constituents for expanding Taiwan's international space. As for substantive political gains, membership could enable Taiwan to establish high-level bilateral diplomatic channels with its neighbours, channels that had been largely blocked since 1971 because of its contested statehood.

In sum, both political rivals, partly driven by perceived gains from their membership of APEC, put accession as the first priority, thereby making concessions over negotiations in order to achieve their top objective.

\section{Convergence of Interests among Actors Other Than Beijing and Taipei}

During the diplomatic process leading up to the first enlargement of APEC, the impact of what Robert Keohane and Joseph Nye describe as "the multiple channels of

\footnotetext{
${ }^{81}$ Interview with Chiang Pin-k'un, the then Vice Minister of Economic Affairs, Taipei, 10 November 1997.

${ }^{82} \mathrm{Hu}$, Yu-li. 1991. "Duozuoshaoshui jiaru yataijinghehui Nanhan youzou liangan he Xianggang sanfang tongshi ruhui queshi youkeneng" (Doing more and talking less: South Korea's shuttle diplomacy involved both sides of the Strait and Hong Kong and may lead to simultaneous participation by three parities), Lianhe Bao, 21 July.

${ }^{83}$ Geldenhuys 2009.
} 
contacts among societies" ${ }^{\prime 84}$ became critical to Taipei's accession. Besides the Chinese and Taiwanese officials, additional key players included Taiwanese business leaders, the Korean official mediator and American officials. Arguably, each player was driven by different interest calculations and it was the convergence of their interests that contributed to Taiwan's accession. Since the converging interests of Taiwanese and Chinese state actors have already been analysed, this section will examine the convergence of interests among the Taiwanese non-state actors and the Korean and American state actors.

First, Taiwanese business players utilized their private sector resources to facilitate Taipei's accession because of their interest in breaking their country's international isolation, which overlapped with that of the state. According to C.F. Koo, "There are many countries with which we do not have diplomatic relations, and in striving to join international organizations we must use the strengths of civil industry and business to influence representatives of each country and thus through them influence their governments." ${ }^{, 5}$ These non-state actors utilized regional NGO settings to lobby for Taiwan's entry and gathered information for Taipei. For instance, Taiwanese PECC members invited their NGO counterparts, especially those with influence on their governments, to Taipei to lobby for Taiwan's membership. ${ }^{86}$ They also used their NGO connections to gain acceptance as Taipei's unofficial representatives in dealing at the official level, illustrated by Koo's attendance of the opening banquet of the inaugural meeting.

As Lawrence T. Woods argues, "There is a possibility that NGOs may at times be better at performing tasks of interest to states than states themselves or IGOs." While the Taiwanese state actor found the utility of formal diplomatic channels lacking because of its position as a contested state, its societal actors better served the state interests by utilizing their private sector resources, thereby bypassing barriers in the formal channels. Hence, multiple channels engineered by Taiwanese economic elites helped the state actor in its bid to join APEC. During the process, official channels did function, illustrated by a Taiwanese diplomat's low-profile presence in the surroundings of the inaugural meeting and later by the diplomatic negotiations. However, these official channels were supplemented by the unofficial ones, especially when the Taiwanese diplomat was excluded from the inaugural meeting. It was Koo that attended the opening banquet, whereas his official partner stayed outside the official gathering. By utilizing his "unofficial" status as the PBEC representative at the banquet, Koo pursued the official interest of Taiwan - to be admitted to the IGO.

\footnotetext{
${ }^{84}$ Keohane and Nye 1977, 24-25.

${ }^{85}$ Wei 1992, 89.

${ }^{86}$ Interview, C. K. Chang.

${ }^{87}$ Woods 1993, 15.
} 
His unofficial status thus became blurred and yet his interest overlapped with that of his country.

Second, Korea's mediation was important to Taiwan's membership and its success resulted from the special Taipei-Seoul-Beijing relationship and the wellrespected diplomatic skill of the leading Korean negotiator. Taipei-Seoul diplomatic channels were smoother than those between other APEC members and Taipei because South Korea was the only APEC country that still recognized Taiwan. Besides, Seoul was eager to normalize its relations with Beijing, making South Korea a less confrontational negotiating partner to China than the major APEC powers such as the US and Japan would have been. Seoul's success was also due to the honed diplomatic skill of Lee. As Fauver commented, "his demonstrated objectivity in finding a solution was assumed to win the respect of parties negotiating the deal." 88

It was Seoul's perceived future interests that made it keen to conclude the negotiations. As the host of the 1991 meeting, Seoul saw the first enlargement, if achieved, as a way to enhance its international reputation. ${ }^{89}$ Besides, the process of negotiations would hopefully accelerate Seoul-Beijing normalization thereby contributing to its moves towards Nordpolitik due to strategic and economic interests. ${ }^{90}$ The strategic calculation concerned the changing Seoul-BeijingPyongyang relationship. In the mid-1980s, the second wave of East-West détente began to affect the Korean Peninsula resulting in a warming of ties between Seoul and Pyongyang. ${ }^{91}$ However, Seoul aspired to befriend Beijing and Moscow in order to gain the upper hand in dealing with Pyongyang. Seoul's economic calculation was to deepen business relations with China through the pursuit of normalization following accelerating bilateral commercial links since the $1980 \mathrm{~s} .{ }^{92}$

Although Lee stressed that he became the negotiator in his capacity as the chair of APEC SOM, not as a representative of Seoul, ${ }^{93}$ the result of his endeavours benefited his government by bringing the Chinese delegation to Seoul, thereby facilitating bilateral high-level official meetings. The political returns to South Korea were later vindicated by the Seoul-Beijing joint communiqué on normalization on 24 August 1992.

Finally, the American support, driven by interest calculations, was conducive to the accession. ${ }^{94}$ In economic terms, the US saw the importance of including the three economies because of their strong regional links and their individual comparative

\footnotetext{
${ }^{88}$ Interview, Robert Fauver.

${ }^{89}$ Hoon 1991.

${ }^{90}$ Ahn 1991, 816.

${ }^{91}$ Lee 1990.

${ }^{92}$ Clifford, Mark. 1988. “A Slow Boat to China,” Far Eastern Economic Review, 141 (37), 82-83.

${ }^{93}$ Funabashi 1995, 74.

${ }^{94}$ Ding 1992.
} 
advantages which could be useful to other APEC members. Taiwan could especially share its experience in developing the small-and-medium enterprises (SMEs) with industrializing countries in APEC. ${ }^{95}$

In strategic terms, Washington had three considerations. First, America intended to maintain a strategic balance within the region, so having one (China) without the other (Taiwan) would cause problems. "I think it (to exclude Taiwan from APEC) would have been unfortunate to the regional stability and development both economically and strategically," admitted Fauver. Second, America remained behind the scenes while assisting Korea to work in the front for the enlargement in order to avoid a direct Sino-US confrontation. ${ }^{96}$ Third, America chose Korea as the "stalking horse" because of Seoul's position as its reliable ally, and also because of its intention to assist Seoul in strengthening its ties with Beijing through the negotiation process. Because Seoul's Nordpolitik was to move close to Beijing and Moscow so as to dominate relations with Pyongyang, this policy matched Washington's strategic interest in establishing a counterforce against Pyongyang. Henceforth, America wished to help Korea become the mediator in order to move Seoul and Beijing together. ${ }^{97}$

\section{Creative Solutions Embodied in MOUs}

The creative solutions embodied in the MOUs finally led to Taiwan's accession. "Chinese Taipei," Taiwan's designation in APEC, was creative because it offered ample room for respective interpretation by Taiwan and the Mainland. Both could choose to translate this English title for Taiwan into a different version of Mandarin Chinese to echo their respective interpretation of the status of Taipei. The PRC chose to call Taipei "Zhongguo Taibei 中国台北” because Zhongguo was the Mandarin Chinese abbreviation for the PRC, a move that reflected Beijing's sovereignty claim over Taiwan. However, Taiwan chose to call itself “Chung-hua Taipei 中華台北” because Chung-hua was the abbreviation for the ROC. By doing so, Taipei could link its name in APEC to its official designation - at least in front of its Mandarinspeaking constituents.

Furthermore, three face-saving formulae were found for China in some parts of the MOUs, thereby ensuring Taiwan's membership. First, the Taiwanese foreign minister should not attend APEC because China regarded the post as a symbol of Taipei's political sovereignty. Second, the PRC-Korea MOU took note of Beijing's position "that there is only one China," which satisfied Beijing's need to proclaim its

\footnotetext{
${ }^{95}$ Interview, Richard H. Solomon.

${ }^{96}$ Interviews, Robert Zoellick, Richard H. Solomon, and Robert Fauver.

${ }^{97}$ Interview, Robert Zoellick.
} 
status as the sole legitimate government of China. Third, the same MOU noted that "distinction should be made between sovereign states and regional economies as a basis for the consultations." These wordings reveal Beijing's intention to define itself as a sovereign state and Taiwan as a non-state. Arguably, Beijing's position was unilateral because the wording preceding such stance in the MOU was "taking note of," instead of "accepting" or "recognizing." Besides, APEC defined all members as economies, so no distinction should be made between sovereign states and regional economies. ${ }^{98}$ As Fauver commented, "If China made its own stance, that's fine. However, it had no standing in the group and in the official document of APEC." $" 99$ Nevertheless, these unilateral pronouncements helped make Taiwan's accession possible.

\section{Conclusion}

To conclude, Taiwan's APEC accession was an important yet under-studied breakthrough in the contested state's struggle to break its international isolation which had lasted since 1971. The nuanced process leading up to this diplomatic watershed and the complex explanations of Taiwan's success, as analysed above, demonstrate that the China factor does not single-handedly determine the timing and modalities of Taiwan's IGO membership. In September 1991, Qian Qichen argued that Beijing had "taken the most flexible stance on the issue of Taiwan's accession to APEC."100 However, such flexibility is not the only major factor accounting for Taipei's membership, as detailed earlier.

The accession has four positive effects on Taipei's position as a contested state. First, Taiwan's de facto recognition as a state has become consolidated since 1991 because of confirmed states' participation in APEC along with the Taipei delegation, although Taiwan's international legal sovereignty has not necessarily improved accordingly. Second, APEC membership has enabled Taipei to engage in international cooperation with member economies on a wide range of issues, including narrowing the digital divide among members, anti-terrorism, and capacity building for SMEs. Consequently, Taiwanese officials ${ }^{101}$ have worked with their counterparts to deal with pertinent transnational issues, and these deepening inter-governmental linkages are

\footnotetext{
${ }^{98}$ Zhongguo shibao, 12 November 1991.

${ }^{99}$ Interview, Robert Fauver.

${ }^{100} \mathrm{Fu}$, Yi-chieh. 1991. "Qian Qichen: Taiwan xunqiu jiaru guanmaozongxie, Beijing lichang yizhi bijiao huanhe; Taiwan jiaru yataijinghehuiyi yong Zhungguo Taiwan mingcheng" (Qian Qichen: Beijing is relatively moderate concerning Taiwan's attempted GATT accession and Taiwan would join APEC under the title of 'Taiwan of China'), Lianhe bao, 28 September.

${ }^{101}$ These officials are in charge of foreign, economic, financial, agricultural, health, judicial, interior and environmental affairs.
} 
key assets for Taiwan as a contested state. Third, APEC accession has helped Taipei mitigate its legitimacy concerns at home stemming from its thwarted status as a normal state. For instance, the image of an envoy representing Taiwan's president side by side with other heads of state during the annual APEC summit, a practice established since $1993,{ }^{102}$ has sent a powerful message to Taiwanese constituents that Taipei is not absent from this regional summit, albeit not on an equal footing with its regional counterparts. As a senior Taiwanese diplomat insists, APEC membership makes Taiwanese constituents feel that their country "exists" on the international stage. ${ }^{103}$ Fourth, APEC accession has enabled Taiwan to continuously advance its interests through the conduct of bilateral diplomacy outside the formal meetings. For instance, outside the 1991 meeting, Taiwan made its first official contact with Japan at a ministerial level since Tokyo severed ties with Taipei in 1971.

As for the major implications of the study for Taiwan's continuous struggle as a contested state, the study shows that many external actors have facilitated Taipei's accession, thereby challenging Beijing's delineation of the Taiwan issue as an "internal" affair. For its future IGO memberships, Taipei should avoid any unqualified reliance on negotiations with Beijing because it may reinforce Beijing's aforementioned claim regarding Taiwan. ${ }^{104}$ However, China's increasing power implies that Taiwan's struggle to expand its contested statehood will deepen. Even so, overt dependence on Beijing's good will to break isolation is insufficient. Taiwan should also ensure that the functioning of economic statecraft and the conduct of sophisticated diplomacy in various major capitals through multiple channels will continually be in place, using favourable external and internal conditions to its advantage as they rise. ${ }^{105}$

\footnotetext{
${ }^{102}$ The summit comprising heads of state from its members has been held since 1993, with Taiwan barred from sending its president to the meeting. The Taiwanese president then appoints a personal envoy, often agreed upon by the host country in advance, to represent Taipei at the summit.

${ }^{103}$ Interview with a senior diplomat, Taipei, 3 April 2013.

${ }^{104}$ For Taiwan's international space since 2008, see Chan 2013; Wang, Lee and Yu 2011.

${ }^{105}$ Interview with Director-General of Department of International Organizations, Ministry of Foreign Affairs, Taipei, 5 August 2014.
} 


\section{References}

Ahn, Byung-Joon. 1991. "South Korean-Soviet Relations.” Asian Survey 31 (9), 816825.

Australian Background. 1989. Australian Prime Minister's Regional Economic CoOperation Initiative. Washington DC: Australian Overseas Information Service, Embassy of Australia.

APEC (Asia-Pacific Economic Cooperation). 1990a. "Summary Conclusions of the First APEC Senior Official Meeting.” Singapore, 7-8 March 1990.

APEC (Asia-Pacific Economic Cooperation). 1990b. "Summary Conclusions of the Second APEC Senior Official Meeting." Singapore, 21-22 May 1990.

APEC (Asia-Pacific Economic Cooperation). 1990c. "Joint Statement of the APEC Ministerial Meeting.” Singapore, 29-31 July 1990.

APEC (Asia-Pacific Economic Cooperation). 1991. "Summary Conclusions of the Third APEC Senior Ministerial Meeting.” Kyongju, Korea, 27-29 August 1991.

Baker, James. 1989. "Address at the ASEAN Post Ministerial Meeting (PMC) Press Conference. " Department of State Bulletin 89 (2150), 62.

Berg, Eiki and Raul Toomla. 2009. "Forms of Normalisation in the Quest for De Facto Statehood." The International Spectator 44 (4), 27-46.

Bonnor, Jenelle. 1990. "The Politics of Asia-Pacific Economic Co-Operation." master's diss., Australian National University.

Chan, Gerald. 1985. "The 'Two-Chinas' Problem and the Olympic Formula." Pacific Affairs 58 (3), 473-490.

Chan, Gerald. 2013. “'Diplomatic Truce' in Cross-Strait Relations: Limits and Prospects." In Weixing $\mathrm{Hu}$ (ed.), New Dynamics in Cross-Taiwan Strait Relations. Abingdon: Routledge, 97-114.

Chang, Jaw-Ling Joanne. 2010. "Taiwan's Participation in the World Health Organization: The U.S. 'Facilitator' Role." American Foreign Policy Interests: The Journal of the National Committee on American Foreign Policy 32 (3), 131-146.

Chang, John. 1991. "Woguo chuxi disanjie yataijingjihezuo buzhangjihuiyi jingguo" (A Report on the ROC's Participation in the Third APEC Ministerial Meeting). Committee Record, Legislative Yuan Bulletin 80 (96), 300-344.

Cheng, Chu-Yuan. 1992. "The ROC's Role in the World Economy." Issues \& Studies 28 (11), 30-48.

Cho, Hui-Wan. 2005. "China-Taiwan Tug of War in the WTO.” Asian Survey 45 (5), 736-755. 
Deng, Yong. 1997. Promoting Asia-Pacific Economic Co-Operation: Perspectives from East Asia. London: Macmillan.

“Fact Sheet: APEC." 1991. Department of State Dispatch 2 (31), 565.

Ding, Mao-Shih. 1992. “Zuijin zhongmei guanxi” (Report on Recent US-ROC Relations). Committee Record, Legislative Yuan Bulletin 81 (25), 507-536.

Evans, Gareth. 1989. “Australia's Regional Economic Co-Operation Initiative: An Idea Whose Time Has Come." address at the opening of the $12^{\text {th }}$ AustraliaASEAN forum, Perth, 15 May 1989.

Evans, Gareth and Bruce Grant. 1991. Australia's Foreign Relations in the World of the 1990s. Melbourne: Melbourne University Press.

Fell, Dafydd. 2012. Government and Politics in Taiwan. London: Routledge.

Funabashi, Yoichi. 1995. Asia Pacific Fusion: Japan's Role in APEC. Washington DC: Institute for International Economics.

Geldenhuys, Deon. 2009. Contested States in World Politics. New York: Palgrave Macmillan.

George, Alexander L. and Andrew Bennett. 2005. Case Studies and Theory Development in the Social Sciences. Cambridge, MA: The MIT Press.

Gerring, John. 2004. "What Is a Case Study and What Is It Good For?" American Political Science Review 98 (2), 341-354.

Habeeb, William. 1988. Power and Tactics in International Negotiation. Baltimore: Johns Hopkins University Press.

Hartland-Thunberg, Penelope. 1990. China, Hong Kong, Taiwan and the World Trading System. London: Macmillan.

Hawke, Robert James. 1989. "Regional Co-Operation: Challenges for Korea and Australia." speech by the Prime Minister to Luncheon of Korean Business Associations, Seoul, 31 January 1989.

Hawke, Robert James. 1994. The Hawke Memoirs. London: Heinemann.

Hickey, Dennis V. 2007. Foreign Policy Making in Taiwan: From Principle to Pragmatism. London: Routledge.

Hoon, S. J. 1991. "Growing-Up Pains: Formalization of APEC Grouping to Loom Large at Talks," Far Eastern Economic Review 154 (46), 27.

Hsieh, Samuel. 1994. "Yuguohua weihu Zhonghuaminguo yayin huiji de gongxian" (Yu Kuo-Hwa's Contribution to Maintaining the ROC's Membership of Asian Development Bank). In H. C. Chiu (ed.), Zhengzhijian de fengfan (The Elegant Demeanour of a Politician). Taipei: Yu Kuo-Hwa Cultural and Educational Foundation, 89-97.

Ignatiev, Vitaliy. 2012. "Доклад заместителя министра иностранных дел ПМР В.В. Игнатьева на заседании расширенной Коллегии Министерства 
иностранных дел ПМР" (Report of Deputy Minister of Foreign Affairs of the PMR V. Ignatiev at the Meeting of the Enhanced Board of the Ministry of Foreign Affairs of the PMR)..Available at: http://vestnik.mfapmr.org/engine/print.php?newsid=70. Accessed 25 March 2014.

Keohane, Robert O. and Joseph S. Nye. 1977. Power and Independence: World Politics in Transititon. Boston: Little Brown and Company.

Ker-Lindsay, James. 2012. The Foreign Policy of Counter Secession: Preventing the Recognition of Contested States. New York: Oxford University Press.

Kim, Samuel S. 1995. "China's Pacific Policy: Reconciling the Irreconcilable." International Journal 50 (3), 461-487.

Klintworth, Gary. 1995. New Taiwan, New China: Taiwan's Changing Role in the Asia-Pacific Region. Melbourne: Longman.

Koo, C. F. 1989. "Taipingyangjingjihezuo buzhanghuiyi guancha baogao" (Observation Report on APEC Ministerial Meeting). confidential report to the Ministry of Foreign Affairs, Taipei, November.

Krasner, Stephen D. 1999. Sovereignty: Organized Hypocrisy. Princeton: Princeton University Press.

Krasner, Stephen D. (ed.), 2001. Problematic Sovereignty: Contested Rules and Political Possibilities. New York: Columbia University Press.

Lardy, Nicholas R. 1994. China in the World Economy. Washington DC: Institute for International Economics.

Lee, Ming 1990. "ROC's Relations with the Two Koreas: Past, Present, and Future." Issues \& Studies 26 (10), 84-98.

Shirk, Susan L. 1996. "Internationalization and China's Economic Reforms." In Robert O. Keohane and Helen. M. Milner (eds.), Internationalization and Domestic Politics. New York: Cambridge University Press, 186-206.

Solomon, Richard H. 1990a. "Statement at the Joint APEC Press Conference, Singapore, 31 July, 1990.” In C.Y. Lin (ed.), Reports on US-ROC Relations. Taipei: Academia Sinica, 211.

Solomon, Richard H. 1990b. "Asian Security in the 1990s: Integration in Economics, Diversity in Defense." Department of State Dispatch 1 (10), 243-248.

Solomon, Richard H. 1991. "Review of the Presidential Discussion." Department of State Dispatch 2 (27), 486.

Tansey, Oisin. 2007. "Process Tracing and Elite Interviewing: A Case for NonProbability Sampling." PS: Political Science \& Politics 40 (4), 765-772.

Wang, T. Y. 2006. "Taiwan's Bid for UN Membership.” In Edward Friedman (ed.), China's Rise, Taiwan's Dilemmas and International Peace. London: Routledge, 174-192. 
Wang, T. Y., Wei-Chin Lee and Ching-Hsin Yu. 2011. "Taiwan's Expansion of International Space: opportunities and challenges." Journal of Contemporary China 20 (69), 249-267.

Wei, Hung-chin. 1992. “Opening Doors to International Organizations.” Sinorama 17 (85), 83-91.

Woods, Lawrence T. 1993. Asia-Pacific Diplomacy: Nongovernmental Organizations and International Relations. Vancouver: UBC Press.

Woolcott, Richard. 1994. "Diplomatic ping-pong paid off," The Australian, 14 November.

Yahuda, Michael. 1996. "The International Standing of the Republic of China on Taiwan." The China Quarterly 148, 1319-1339.

Yin, Nai-jing. 1991. "Wo cengfu Han cuoshang" (Taiwan went to Korea for negotiations), Zhongguo shibao, 29 August.

Yin, Robert K. 1994. Case Study Research: Design and Methods. Thousand Oaks: Sage.

Youngblood, Ruth. 1990. “Asian-Pacific group can't agree on 'three Chinas'," United Press International, 31 July.

Zhongguo shibao. 1991. "Mingcheng sheji zhuquan? Butong de quanshi" (Title involved sovereignty? Different interpretations), 12 November. 